DOI: https://doi.org/10.32839/2304-5809/2019-10-74-26

UDC 140.8

Mozgovoy Leonid, Sushenko Inna

Donbass State Pedagogical University

\title{
ANTHROPOMISTIC MEASUREMENTS OF THE PHILOSOPHY OF BUDDHISM
}

Summary. The reality of the modern world appears in the mode of permanent crisis, because in its own civilizational development, mankind over the past half century has reached a new dimension of its own influence on the surrounding world. The most fruitful and large-scale this dialogue of the Western world with the traditions of the East: Buddhism and Taoism. The search for a flexible model of holistic subjectivity, which overcame the limitations of European logocentrism and its derivatives, leads to the Eastern wisdom of everyone who seeks spiritual development.

Keywords: Buddhism, mystical philosophy, eastern philosophy, anthropology, mysticism.

Мозговий Л.І., Сущенко I.O.

Донбаський державний педагогічний університет

\section{АНТРОПОЛОГІЧНІ ВИМІРИ ФІЛОСОФІї БУДДИЗМУ}

Анотація. Реальність сучасного світу постає в модусі перманентної кризи, адже у власному цивілізаційному розвитку людство за останні півстоліття досягло нового виміру власного впливу на навколишній світ. 3 рівнем «антропологічної кризи» XX ст. світоглядний фокус зміщуеться в площину «екологічної кризи» - вірогідною глобальної катастрофи. Світоглядний клімат сучасної епохи визначається станом фотурологічного шоку, коли майбутне вже не здатне обіцяти людству певний оптимістичний ідеал, і світоглядні пошуки повинні зосередитися на минулому. У такому контексті набувають актуальності історико-фрілософрські дослідження світоглядних парадигм, альтернативних західноевропейським, зокрема буддизму, в рамках якого утворилися різноманітні вчення і практики набуття антропомістіческого досвіду звільнення особистості за приводу не зовнішніх, а суто внутрішніх фракторів. 3 рівнем «антропологічної кризи» XX ст. ідеологічний фокус зміщується до площини «екологічної кризи» - ймовірної глобальної катастрофи. Світоглядний клімат сучасної епохи визначається станом фртурологічного шоку, коли майбутне вже не в змозі обіцяти людству певний оптимістичний ідеал, а світоглядний пошук повинен орієнтуватися на минуле. У цьому контексті набувають актуальності історичні та фрілософські дослідження світоглядних парадигм, які є альтернативними Західній Свропі, зокрема, буддизму, в рамках яких формувалися різні вчення та практики набуття антропомічного досвіду визволення особистості за допомогою внутрішніх фракторів. В умовах антропологічної кризи, викликаної еволюційним переходом фрілософрії від некласичного до постнекласичного способу конституювання світогляду на різних рівнях системи суспільної свідомості, діалогу між европейською цивілізацією та іншими світовими культурами стає актуальним. Початок двадцять першого століття характеризуеться черговим сплеском інтересу до містицизму. Причини џого різні, $\mathrm{i}$ часто зводяться не до одного фрактора, а до цілого ряду процесів, що відбуваються в суспільстві. І якщо протягом довгого часу у вітчизняній фрілософрській літературі містицизм цілому зізнавався псевдонаукових феноменом, то зараз відбувається переосмислення цього явища, так само вимагає звернення до тих релігійно-фрілософрських систем, в яких містищизм і містичні практики складають їх сутність, зокрема до дзен-буддизму.

Ключові слова: Буддизм, містична філософія, східна фрілософія, антропологія, містицизм.

Relevance. Buddhism is one of the most an-

$\boldsymbol{R}_{\text {cient }}$ and influential world religions. In the process of its formation and distribution, he had a significant impact on the development of social relations and the culture of many eastern peoples.

State of scientific development. Systematic studies were carried out by Ruegg, J. Tucci, C. Vogel, E. Koine, G. Ponter, J. Hopkins, E. Obermiller, V.I. Rudym, B.I. Kuznetsov.

The purpose of this article is to study the philosophy of Buddhism.

Research results. Now, when there is a kind of «return» to the irrational-mystical philosophy, statements about the intrinsic value of mystical practices in the knowledge of the inner world of man are heard more and more often. Showing great interest in the irrational-mystical philosophy, modern science and philosophy are trying to rethink its ontology, anthropological attitudes, epistemological ideas.

It is the scientific paradigm of Eastern philosophy that recently claims to reveal the essence of the anthropological one. This current, in the opinion of many scientists (F. Capri, S. Grof, K. Wilbera, and others), is increasingly claiming the role of a new human philosophy. Its initial postulate: philosophy should not be aimed at studying individual manifestations of the hu- man psyche, but at understanding the nature of man as a whole - in a broad world outlook, based largely on the constructions of quantum physics and Eastern (or rather, Buddhist) anthropology [2, p. 114].

These two attitudes are the pure embodiment of two types of worldview of the cosmos and personality in which the ontological choice is behind the true-false opposition: the subject of choice is not the «subject» of the judgment, which can be true or false, but an open-ended living strategy. Buddhism begins with what postmodernism ends today: from the strengthened and polemical affirmation of the death of the subject, the illusoriness of all substantive foundations is presented as a stream of states. For postmodernist consciousness, Buddhism acts as a natural further step, as a direct way to deepen the experience achieved and experienced, forcing Carl Jung to recall that in the historical perspective, the integration of Buddhism with Western culture will be the most important feature of the century. That is why modern philosophy seeks to show the essence of the paths of spiritual growth, referring to the mystical tradition, which combines deep knowledge and subtle practical art, carrying fundamental consequences for various spheres of thought and life.

The irrational-mystical philosophy of Buddhism in this direction acts not only as an object of research, 
but also as a guideline for the development of man. By critically analyzing the old research methodology, based primarily on sociology, modern researchers are trying to bring back the irrational-mystical problematics of philosophy, since «different sociological concepts of religion characterize it only externally, describing and explaining its functioning, but not its essence. Irrational-mystical phenomena include, first of all, the philosophical basis of the goal and the task, by which it is the achievement of a special (altered) state of consciousness, the control over concentration and breathing, the achievement of a certain intuitive cognition. Achieving nirvana in Buddhism is the path of spiritual development of man, his mental transformation.

The main criterion for identifying the conceptual foundations of mystical teachings is the category of the irrational. Irrationalism should be understood as a "philosophical trend proclaiming the primacy of the irrational principle, which is the main characteristic of the world itself. The irrational is fundamentally incompatible with the mind and its capabilities, it is beyond its limits, illogical and incompatible with rational thinking. Irrationalists see the basis of the world view in a different nature to it, the result of which is the very irrational nature of being. In irrationalism, the world around us and the process of searching for truth flow through understanding it with the help of non-rational aspects of a person's spiritual life: will, feelings, intuition, direct contemplation, imagination, instinct, unconscious, mystical «illumination» and others.

Analysis of this problem requires clarification of the very concept of mysticism. The word «mystic» in translation from Greek means "mysterious» and is used to denote a special practice aimed at achieving direct communication and union with God in ecstatic acts of revelation. Mystical experience has the character of "immediacy», "intuition" and is accompanied by extremely intense emotional manifestations. This approach defines mysticism as the mindset of man, his own being, not in the coordinates of our four-dimensional world, but in the hierarchy of the spiritual structure of the universe as a whole. So, the mystical in the context of our research is considered as a form of manifestation of the irrational. The basis for the independence of the phenomenon of mysticism is the "mystical experience», which is the experience of the transcendence of subjectivity in everyday conditions of experience; Mystical experience has a clearly expressed value-emotional nature and can be a source of a harmonizing relationship to the world. Heinrich Dumoulin draws attention to the fact that the ideas about the mystical component of knowledge have expanded considerably. It became necessary to draw a line between the concept of supernatural mysticism, divine grace, and the concept of natural mysticism.

In the East, as Bergson notes in his work «Two sources of morality and religion," the development of mysticism was somewhat different from the ancient Greek and, basically, was carried out in two ways this is the use of strong drinks "catfish" and with the help of special exercises that were used to slow down the psyche was systematized in "yoga». This practice has been preserved through brahmanism, jainism and buddhism. "In fact, yoga was, in accordance with the time and place, a more accessible form of mystical contemplation or a holistic system that included this form.

On the one hand, Buddhism was not more fundamentally different from other religions but more scientific, and even more mystical: "The state in which he leads his soul is on the other side of con- sciousness. He achieves nirvana, suppressing desires in life and karma after death «...if you take all this into account, then without hesitation we will see mysticism in Buddhism» [1, p. 240].

Further, A. Bergson explains his opinion: «But at the same time, we understand why Buddhism is not complete mysticism. The latter is action, creativity, love». Complete mysticism is found in India, later only in the teachings of Ramakrishna and Vivekananda» [1, p. 243].

A large circle of diverse research literature has been formed around Buddhist mysticism, but it is mostly descriptive in general. It can be noted that at present from the available works on Buddhism, both domestic and foreign scholars, it is possible to find an individual assessment, an individual approach to a particular problem, however, there is no holistic vision of the doctrine of Buddhism as an anthroposystical philosophy.

To understand the anthropomistic ideas of the philosophy of Buddhism, it is necessary to trace the formation of the conceptual foundations of the most influential areas of Buddhism - Hinayana and Mahayana. To accomplish the outlined task, we will rely on modern historical and philosophical research.

The texts of Nagarjuna became the philosophical basis of the Mahayana teachings, but before analyzing them, it should be noted that the role of philosophy in Buddhism was very noticeably different from that assigned to it in European science.

V. Varma, a researcher of early Buddhism, states: «Some authors are critical of the fact that Gautama Buddha does not positively categorize mystical practices (Dhyana, samadhi, prajna), although he recognizes their effectiveness, the Buddha ignores the need for explication of the highest principles.

Buddhism is characterized by the position of a certain epistemological reductionism: «Buddha avoided both metaphysical and dialectical discussions on the definition of absolute reality and truth». The mysticism of the philosophy of early Buddhism is associated with the constitution of the out-of-electoral, intuitive sources of knowledge, but it does not articulate faith in a higher reality. E. Torchinov draws attention to the fact that ancient philosophy was addressed to the secular man, although there existed various esoteric traditions that required initiation, and Buddhist philosophy, in essence, is esoteric in full, it implies not only meditative perception, but also individual transfer of teaching from teacher to student. This is called the transmission line or the teacher's tradition which consists in the fact that knowledge was transmitted in European culture, and in the Buddhist tradition the mystical component of the teaching [5, p. 45].

All the elements of being are interconnected and therefore unreal, and the real is only the One - incomprehensible from the outside, inexpressible by words and concepts. If in Hinayana, existence doubles into specified and unspecified realities, then in Mahayana it merges into supreme unity. The term "shunya" means emptiness, and in no way means non-existence, but only the relativity of being: «We are relativists, we are not negativists," wrote an eminent student of Nagarjuna Chandrakirti .

Madhyamika does not deny reality, but doctrines about it. Nagarjuna denies the absolute being of the Hinayanist extinct Buddha as an eternal inanimate substance, correlated with the flow of existence and therefore devoid of absolute being. The true Buddha is identical with nirvana, moreover, he is identical with the universe. It is believed that millions of creatures 
should master the Buddha nature, that is, their ability to achieve Enlightenment. According to the definition of the outstanding Russian Buddhologist F. Shcherbatsky: «All of them were interconnected, mutually determined, and therefore unreal. And nothing, not excluding the integrity of these elements, the integrity of integrity, like the universe itself, regarded as unity, as the only peculiar real substance, could not be perceived as real in the semantic horizon of a limb.

Among the texts of Nagarjuna, the central place is occupied by the "Mula-madhyamaka-karika» in which the teaching of the Void is fully revealed, according to which the soul as an absolute substance is absent, since the spiritual and mental phenomena of the human consciousness are completely dependent on external phenomena. The relativity of all categories, which are usually referred to as absolute, is proved similarly. The translator and researcher of the texts of Nagarjuna V. Androsov writes: «In the phenomenal reality, dharma particles manifest themselves in time and space by combinations determined by the laws of causality and essential conditions of existence, for example, analysis of any conscious act shows that for every single minute the dharma is a particle of consciousness (citta) is in combination with at least ten satellite dharmas that appear in accordance with the law of interdependent origin. Such initial positions in ontology opened up a wide horizon of possibilities not only for the analysts of Vaybkhashiki, but also for mystics for self-deepening, meditation on the structures of the individual psyche».

However, Nagarjuna is far from nihilism to transcend the duality of being and non-being to find an unsurpassed state, in denying knowledge and object, the belief that nothing happens in denial of unity andmultiplicity, probability and reach.

The methodological basis of Nagarjuna's thought was the assertion that everything that exists (all dharmas) is causally caused that dharmas do not exist by themselves, do not have their own being and their own essence. Any element exists only in connection with all other elements - it is nothing but the ephemeral generation of the totality of the causes that caused it to exist and for this have no being.

So, all the elements of "reality" are just phantoms and appearances. None of the elements, noted Nagarjuna, has being, since its being is borrowed from other elements that also borrow it, and this is by no means true being. Accordingly, all the elements that consist of them are empty. Hence the name of the philosophical doctrine of Nagarjuna - shunyavada, i.e. the study of the Void (shunya, shunyata). In particular, Nagarjuna sharply criticized such categories as causality, motion, time, and others.

The streams of empirical existences are individualized by a certain force of becoming and birth together with other forces inherent in each dharma particle, namely the forces of birth, continuity, decay, disappearance, which function simultaneously and at any moment.
What conclusions did Nagarjuna? First, it is impossible to adequately describe reality with the means of a natural language, because linguistic forms do not correspond to the essence of reality. Philosophical thinking, which operates with concepts and categories, is also not satisfactory. Logical thinking cannot comprehend reality, language cannot describe it. So, no ontology, no "science of being" is impossible, because it is always connected not with reality, but with our ideas about it, or even with some kind of pseudo-reality, constructed by our mental skills and false ideas. Therefore, everything real is indescribable, and everything that is described is unreal. However, what is inaccessible to the logic of discourse can be understood in the act of wisdom-understanding.

A bodhisattva sees the world as it is, without our perception, deforming it, which affirms the identity of sansara and nirvana: if these categories are thinking in opposites, then they turn out to be empty, empty and interdependent phantoms. So, sansara and nirvana are one and the same, but considered as if from different positions. The world as a set of causes and conditions that the subject sees is sansara; the same world (perceived by the bodhisattva waking consciousness), freed from the burden of causes, conditions, and other chains imposed on it by ignorance, is nirvana.

Secondly, Nagarjuna considered time, movement, space as internally contradictory ideas; all dharmas are also empty, non-attribute, and vague in their reality. However, in the experience we are guided by these ideas, since they can be considered conditionally real, valid in the sphere of everyday experience. True reality is identical, however, to the world of illusion, as nirvana is identical to samsara, and is grasped by the yogi in the act of understanding absolute, unconditional truth beyond the ordinary experience. From the standpoint of relative truth, it follows that all living beings are immersed in the quagmire of samsara, the cycle of birth-death, from which they can get out and find nirvana. From the standpoint of absolute truth, all living beings are originally Buddha and have always been, are and will be in nirvana. Bodhisattva knows the difference between two truths.

The Buddhist yogi returns this process back, freeing the mind from its content, as a result of which the mind ceases to be projected outward and is sent to itself, then liberation occurs - nirvana. The path that leads to this release is described in detail in the Yogachar treatises on the stage of the psychotechnical practices of the transformation of consciousness to get out of the birth-mortality circle.

Conclusions. So, each supporter of Buddhism recognized only self-evident for the natural consciousness: the existence of the flow of life and its inherent variability of suffering through the observance of elementary moral norms and the prevention of extremes should allow a person to get rid of preferences that cause suffering, which means to find peace, that is, nirvana. Buddhism does not require any other theoretical propositions.

\section{References:}

1. Bergson, A. Dva istochnika morali i religii; per. s fr. A. Gofmana. Moskva : KANON, 1994. 384 s.

2. Grof, S. Psihologiya budushchego. Moskva : ACT, 2001. 325 s.

3. Kapstein, M.T. The Tibetans Text. Oxford : Blackwell Publ., 2016. 360 p.

4. Rheingans, J. The eighth Karmapa's life and his interpretation of the great seal : philosophy dr thesis Text. Univ. of the West of England, collegiate Bath Spa University. Bristol, 2018.

5. Samuel, G. The Siddha as a cultural category Text. Holy Madness: portraits of Tantric Siddhas / ed. R. Linrothe. New York; Chicago : Serindia Publications and Rubin Museum of Art, 2006.

6. Yong, A. Tibetan Buddhism going global? A case study of a contemporary Buddhist encounter with science Text. Journal of Global Buddhism. 2008. 